\title{
Medical Student's Perception And Preferences About Peer Physical Examination (PPE)
}

\author{
Manjunath $\mathbf{H}^{1}$, Venkatesh $\mathbf{D}^{2}$, Taklikar $\mathbf{R} \mathbf{H}^{3}$, Vijayanath ${ }^{4}$ \\ ${ }^{1}$ Assistant Professor of Physiology, Navodaya Medical College, Raichur \\ ${ }^{2}$ Professor \& Head of Physiology, M S Ramaiah Medical College, Bangalore \\ ${ }^{3}$ Professor \& Head of Physiology, Navodaya Medical College, Raichur \\ ${ }^{4}$ Professor of Physiology, Navodaya Medical College, Raichur
}

\section{Abstract}

There is greater emphasis on clinically oriented teaching and early clinical exposure for medical students. There is limitation to practice and perfect the skills on sick patients. Hence, standardized patients are used for practice of clinical skills. However non-availability of trained standardized patients, high cost of employing them poses a challenge to training medical students. The viable alternative is to use the peers for skill training. It can be a potential area of student discomfort or inappropriate behavior by classmates or tutors. Present study assesses the attitude of students towards Peer Physical Examination (PPE). Fifty three third term medical students (23 males and 30 females) were administered a structured and validated questionnaire with 15 questions to assess elements of comfort, professionalism, appropriateness and value of PPE. Students responded to questions using a five-point Likert scale, where $1=$ strongly agree, and $5=$ strongly disagree. The pattern of response was similar for male and female students. $81.82 \%$ were comfortable with PPE for practice of clinical skills. $32.90 \%$ were comfortable examining peers of opposite sex. $18.04 \%$ felt it was appropriate to perform breast, genital and rectal examinations on peers. $2.17 \%$ agreed to volunteer for such examination.Majority of students preferred PPE to standardized patients for practice of clinical skills. PPE was preferred as it provided valuable feedback, better learning experience, and felt examining classmates was comfortable \& appropriate. However they felt inappropriate to volunteer or examine breast, inguinal, genital regions of classmate as a part of PPE.

Key Words: Peer Physical Examination, Standardized patients, clinical skills, early clinical exposure

\section{INTRODUCTION}

$\mathrm{M}$ odern medical education, teaching-learning approaches now laid emphasis on students acquiring knowledge, skills and attitudes relevant to medical practice. Peer physical examination (PPE) is a method whereby students learn the skills using each other as subject for examination. It is employed in many medical institutions to teach functional anatomy and skills of clinical examination. The need for PPE in terms of learning clinical skills is based on the fact that there has been an increase in the number of medical students, clinical skills teaching in the pre-clinical years require that students have access to subjects to learn and practice their clinical skills. Hence, standardized patients are used for practice of clinical skills. However, non-availability of trained standardized patients, high cost of employing them poses a challenge to training medical students in our country. The viable alternative is to use the peers for skill training. PPE is an active educational choice due to its perceived advantages for students. PPE enables students to become familiar with clinical examination and communication skills before interacting and examining real patients [1]. It offers an opportunity to learn even by committing mistakes which cannot be done on real patients [2]. It helps them to learn what is 'normal' by examining healthy students before examining patients with abnormal features [3]. It also facilitates the students to receive feedback regarding the skills acquired from their peers [1]. After being examined, students develop empathy for their patients, understanding what it feels like to be examined [4]. It can be a potential area of student discomfort or inappropriate behavior by classmates or tutors and one would

\section{Address for correspondence* Dr.Manjunath $\mathbf{H}$}

Assistant Professor of Physiology

Navodaya Medical College, Raichur.

E-mail: aaryanmunch@gmail.com

Mobile: +919980338843 expect PPE to have poor acceptance by students. However, this is not so, according to existing literature based on studies in western countries. O'Neill et al using a questionnaire based survey in Manchester (UK) found that $94 \%$ of medical students were willing to examine non-intimate areas (head and neck, arms and shoulders, feet and legs, abdomen and hips) of their peers. Using a questionnaire survey after a year of PPE teaching, Chang and Power found that $97 \%$ of medical students from Minnesota (USA) agreed that they were comfortable with PPE of nonintimate areas: both examining and being examined. But such literature or studies on PPE is not available in India. Hence, we tried to assess the attitude of our students towards PPE.

\section{MATERIALS AND METHODS}

In this study, cross-sectional design was used to assess the attitude of students who have completed first year MBBS towards PPE. Institutional research ethical clearance was obtained prior to the data collection. Written informed consent was obtained from each of the participant and the identity of the student was kept confidential throughout the study. Fifty three medical students (23 males and 30 females) were administered a structured and validated questionnaire with 15 questions to assess elements of comfort, professionalism, appropriateness and value of PPE. Students responded to questions using a five-point Likert scale, where $1=$ strongly agree, and $5=$ strongly disagree. The responses were expressed as percentage and the comparison was done by using chi square test.

\section{RESULTS}

The pattern of response was similar for male and female students. $81.82 \%$ were comfortable with PPE for practice of clinical skills. $32.90 \%$ were comfortable examining peers of opposite sex. Majority of students had reservations about performing or being subject for breast, genital and rectal examinations. However $18.04 \%$ felt it was appropriate to perform examination on peers. $2.17 \%$ agreed to volunteer for such 
Table 1: Responses of Males in percentage

\begin{tabular}{|c|c|c|c|c|c|c|}
\hline $\begin{array}{l}\text { Sl. } \\
\text { NO }\end{array}$ & & 1 & 2 & 3 & 4 & 5 \\
\hline 1 & $\begin{array}{l}\text { I am comfortable with other medical students practicing Peer } \\
\text { Physical Examination on me }\end{array}$ & 17 & 70 & 0 & 13 & 0 \\
\hline 2 & $\begin{array}{l}\text { I am comfortable with me practicing Peer Physical Examination on } \\
\text { other classmates }\end{array}$ & 35 & 61 & 0 & 4 & 0 \\
\hline 3 & $\begin{array}{l}\text { Being undressed for PPE in front of a group of my peers would } \\
\text { make me feel exposed }\end{array}$ & 17 & 48 & 4 & 22 & 9 \\
\hline 4 & $\begin{array}{l}\text { I am concerned that I might get aroused while taking turns } \\
\text { practicing PPE skills with a classmate }\end{array}$ & 0 & 22 & 26 & 39 & 13 \\
\hline 5 & $\begin{array}{l}\text { I am comfortable taking turns practicing exam skills with another } \\
\text { student of same sex }\end{array}$ & 43 & 43 & 0 & 10 & 4 \\
\hline 6 & $\begin{array}{l}\text { I am comfortable taking turns practicing exam skils with another } \\
\text { student of opposite sex }\end{array}$ & 17 & 22 & 9 & 26 & 26 \\
\hline 7 & $\begin{array}{l}\text { Practicing Peer Physical Examination on fellow classmates is an } \\
\text { appropriate part of medical training }\end{array}$ & 43 & 52 & 5 & 0 & 0 \\
\hline 8 & $\begin{array}{l}\text { Practicing Peer Physical Examina tion on fellow classmates is a } \\
\text { valuable learning experience }\end{array}$ & 48 & 44 & 4 & 4 & 0 \\
\hline 9 & $\begin{array}{l}\text { I get valuable feedback about my exam technique from a fellow } \\
\text { student }\end{array}$ & 52 & 39 & 9 & 0 & 0 \\
\hline 10 & $\begin{array}{l}\text { I am comfortable setting limits with another students before being } \\
\text { examined by them ('Please don't perform ---- part of the } \\
\text { exam.") }\end{array}$ & 43 & 35 & 9 & 13 & 0 \\
\hline 11 & Practicing PPE on classmates strains my relationship with them & 13 & 9 & 22 & 26 & 30 \\
\hline 12 & $\begin{array}{l}\text { Taking turns practicing PPE on my fellow classmates is preferable } \\
\text { to learning on standardized patients (i.e., paid models) }\end{array}$ & 22 & 52 & 13 & 13 & 0 \\
\hline 13 & $\begin{array}{l}\text { Taking turns practicing PPE with classmates allows for more time } \\
\text { to learn exa mination skills more properly }\end{array}$ & 61 & 26 & 9 & 4 & 0 \\
\hline 14 & $\begin{array}{l}\text { Performing breast, genital, and rectal exams on fellow classmates is } \\
\text { an appropriate part of medical training }\end{array}$ & 9 & 17 & 18 & 39 & 17 \\
\hline 15 & $\begin{array}{l}\text { I would volunteer as a subject for practicing breast/ } \\
\text { genital and rectal exams by my classmates }\end{array}$ & 0 & 4 & 13 & 30 & 53 \\
\hline
\end{tabular}

Table 2: Responses of Females in percentage

\begin{tabular}{|c|c|c|c|c|c|c|}
\hline $\begin{array}{l}\text { Sl. } \\
\text { NO }\end{array}$ & & 1 & 2 & 3 & 4 & 5 \\
\hline 1 & $\begin{array}{l}\text { I am comfortable with other medical students practicing Peer } \\
\text { Physical Examination on me }\end{array}$ & 27 & 50 & 7 & 16 & 0 \\
\hline 2 & $\begin{array}{l}\text { I am comfortable with me practicing Peer Physical Examination on } \\
\text { other classmates }\end{array}$ & 23 & 60 & 4 & 10 & 3 \\
\hline 3 & $\begin{array}{l}\text { Being undressed for PPE in front of a group of my peers would } \\
\text { make me feel exposed }\end{array}$ & 50 & 30 & 7 & 10 & 3 \\
\hline 4 & $\begin{array}{l}\text { I am concerned that I might get aroused while taking turns } \\
\text { practicing PPE skills with a classmate }\end{array}$ & 3 & 10 & 24 & 40 & 23 \\
\hline 5 & $\begin{array}{l}\text { I am comfortable taking turns practicing exam skills with another } \\
\text { student of same sex }\end{array}$ & 53 & 41 & 3 & 3 & 0 \\
\hline 6 & $\begin{array}{l}\text { I am comfortable taking turns practicing exam skills with another } \\
\text { student of opposite sex }\end{array}$ & 3 & 23 & 10 & 43 & 21 \\
\hline 7 & $\begin{array}{l}\text { Practicing Peer Physical Examination on fellow classmates is an } \\
\text { appropriate part of medical training }\end{array}$ & 27 & 34 & 13 & 23 & 3 \\
\hline 8 & $\begin{array}{l}\text { Practicing Peer Physical Examination on fellow classmates is a } \\
\text { valuable learning experience }\end{array}$ & 40 & 30 & 13 & 17 & 0 \\
\hline 9 & $\begin{array}{l}\text { I get valuable feedback about my exam technique from a fellow } \\
\text { student }\end{array}$ & 41 & 43 & 13 & 3 & 0 \\
\hline 10 & $\begin{array}{l}\text { I am comfortable setting limits with another students before being } \\
\text { examined by them ('Please don't perform ---- part of the } \\
\text { exam.') }\end{array}$ & 40 & 30 & 10 & 13 & 7 \\
\hline 11 & Practicing PPE on classmates strains my relationship with them & 0 & 7 & 23 & 40 & 30 \\
\hline 12 & $\begin{array}{l}\text { Taking turns practicing PPE on my fellow classmates is preferable } \\
\text { to learning on standardized patients (i.e., paid models) }\end{array}$ & 30 & 30 & 20 & 17 & 3 \\
\hline 13 & $\begin{array}{l}\text { Taking turns practicing PPE with classmates allows for more time } \\
\text { to learn exa mination skills more properly }\end{array}$ & 37 & 47 & 3 & 13 & 0 \\
\hline 14 & $\begin{array}{l}\text { Performing breast, genital, and rectal exams on fellow classmates is } \\
\text { an appropriate part of medical training }\end{array}$ & 3 & 7 & 24 & 23 & 43 \\
\hline 15 & $\begin{array}{l}\text { I would volunt eer as a subject for practicing breast/ } \\
\text { genital and rectal exams by my classmates }\end{array}$ & 0 & 0 & 16 & 17 & 67 \\
\hline
\end{tabular}


examination. Majority of the students expressed that they could get valuable feedback from their peers about the technique of examination. Further, they opined that PPE was preferred to examination of standardized patients. (Tables: 1,2 )

\section{DISCUSSION}

Findings of our study underline the high level of acceptability of PPE for non-intimate body regions amongst medical students, as indicated in previous studies based in western countries [3, 5 and 6]. Our results were consistent with earlier studies, suggest that students were comfortable with same gender rather than opposite-gender during PPE, Further they were willing to examine their peers than being examined themselves $[5,6]$. These preferences were especially evident for PPE of intimate body regions (i.e. breast, groin region without genital exposure, and the genitals). Our gender-related findings were consistent with earlier research, which had demonstrated that females were less comfortable with PPE than males. The students were willing to engage in same-gender PPE [5, 6 and 7]. There are various reasons that could account for these gender differences. Insights from body image theory suggest that females may be less comfortable with PPE than males because they have higher levels of body surveillance (i.e. constantly viewing their bodies as if they were an outside observer), body shame, were more fearful of critical teasing comments and sexual objectification by the opposite gender [8]. Tutors must be mindful of these gender sensitivities, supervise the PPE process in a way that encourages participation and learning but reduces embarrassment. Medical educators using PPE as an educational strategy to help students learn clinical skills should be reassured that students typically find non-intimate examinations acceptable. Further, quantitative research with more diverse samples is now needed to explore attitudes of medical students towards PPE over longer periods of time. Qualitative research is also needed in greater depth to explore why some of the students were reluctant to engage in PPE.

\section{CONCLUSION}

Majority of students preferred PPE to standardized patients for practice of clinical skills. PPE was preferred as it provided valuable feedback, better learning experience, and felt examining classmates was comfortable \& appropriate.

\section{REFERENCES}

1. Chang E H, Power D V. Are medical students comfortable with practicing physical examinations on each other? Academic Medicine 2000, 75(4):384-389.

2. Wearn A, Bhoopatkar H. Evaluation of consent for peer physical examination: Students reflect on their clinical skills learning experience. Medical Education 2006, 40: 957-964.

3. O'Neill P A, Larcombe C, Duffy K, Dorman T L. Medical students' willingness and reactions to learning basic skills through examining fellow students. Medical Teacher 1998, 20(5): 433-437.

4. Braunack-Mayer A J. Should medical students act as surrogate patients for each other? Medical Education 2001, 35: 681-686.

5. Rees C E, Bradley P, McLachlan J C. Exploring medical students' attitudes towards peer physical examination. Medical Teacher 2004, 26(1): 86-88.

6. Rees C E, Bradley P, Collett T, McLachlan J C. "over my dead body?": The influence of demographics on students' willingness to participate in peer physical examination. Medical Teacher 2005, 27(7): 599-605.

7. Power D V, Center B A. Examining the medical student body: Peer physical exams and genital, rectal, or breast exams. Teaching \& Learning in Medicine 2005, 17(4): 337-343.

8. Rees C E. The influence of gender on student willingness to engage in peer physical examination: The practical implications of feminist theory of body image. Medical Education 2007, 41:801-807. 